\title{
Od Tehničke enciklopedije do Hrvatske tehničke enciklopedije
}

\author{
Zdenko Jecić \\ Leksikografski zavod Miroslav Krleža, Zagreb \\ zdenko.jecic@lzmk.hr
}

SAŽETAK: Hrvatska tehnička baština, povijest i sadašnje stanje tehnike u Hrvatskoj razmjerno su slabo istraženi i dokumentirani u literaturi, a napose nedostaju pregledna, sintetska djela o tom području. Takvo se stanje djelomice odrazilo i u suvremenoj hrvatskoj enciklopedistici. Za razliku od Pomorske ili Šumarske enciklopedije Leksikografskoga zavoda (LZ), Tehnička enciklopedija (TE), koja je kao kapitalno djelo u 13 svezaka dugo bila nezaobilazna literatura studenata tehničkih fakulteta, usredotočila se na makropedijsko tumačenje općih tehničkih pojmova, dok je sustavna obradba povijesti i sadašnjega stanja u Hrvatskoj izostala. Novi projekt LZ-a Hrvatska tehnička enciklopedija (HTE) nastavlja se na $T E$ te predstavlja njezinu nadopunu, uključujući nacionalne teme, obrađujući u člancima opće pojmove, biografije, poduzeća te ustanove, časopise i udruge, nastojeći pritom tekstove prilagoditi najširem krugu korisnika. Projekt HTE oslanja se na vrijednosti tradicionalnoga enciklopedičkoga koncepta organizacije i diseminacije konsolidiranoga znanja, prilagođene digitalnomu dobu, te usporedno dolazi u tiskanom i mrežnom izdanju. Očekuje se da će takav pristup pridonijeti boljemu poznavanju hrvatske tehnike, a time i njezinoj boljoj percepciji u kulturnom i društvenom kontekstu.

Ključne riječi: Tehnička enciklopedija; Hrvatska tehnička enciklopedija; Portal hrvatske tehničke baštine

\section{Uvod}

Tehnika, kao ukupnost iskustveno ili znanstveno utemeljenih vještina, umijeća i postupaka, s potrebnim priborom, pomagalima i strojevima, koji služe za zadovoljavanje ljudskih potreba u stvarnome životu ${ }^{1}$, oduvijek je bila pokretač civilizacijskoga razvoja čovječanstva, određujući stupanj gospodarskoga razvoja, životni standard ili vojnu snagu neke zemlje. To se nije promijenilo ni danas, kada svakodnevni život ljudi, proizvodnja dobara, čak i intelektualni dosezi ovise o tehničkim pomagalima te znanjima o njihovu razvoju i primjeni. Kao važan dio STEM područja, tehničke su znanosti u svijetu i u Hrvatskoj danas među vodećim znanstvenim i visokoškol-

1 »tehnika«, Hrvatska enciklopedija, sv. 10. Zagreb 2008. 
skim područjima prema gotovo svim pokazateljima. U Hrvatskoj je 2014. bilo 43825 studenata na tehničkim fakultetima ${ }^{2}$, što tehničke znanosti smješta na drugo mjesto, iza društvenih, dok je 2016. od ukupno 646 promoviranih doktora znanosti njih $17,6 \%$ bilo iz područja tehničkih znanosti, što je to područje svrstalo na treće mjesto 3 .

Promatrajući povijesni razvoj i trenutačno stanje tehnike u Hrvatskoj, prema svojim postignućima, istaknutim pojedincima i razvojnim središtima, povremenim usponima i padovima, ona ne zaostaje za drugim znanostima i djelatnostima, već prati ukupnost dosega zemlje. Usprkos navedenomu, prema pojavnost u medijima, literaturi, obrazovnim programima osnovnoga ili srednjega školstva, te prema institucionalnoj zastupljenosti, tehnika i tehničke znanosti nisu uvijek zauzimale proporcionalan položaj u usporedbi s drugim disciplinama, odnosno odgovarajuće mjesto u hrvatskome kulturnom i javnome životu.

Usporedno s time, zanimanje za povijest $\mathrm{i}$ trenutačno stanje vlastite struke $\mathrm{u}$ Hrvatskoj tehničari inženjeri pokazuju razmjerno kasno. Jedan od prvih koji je istraživao hrvatsku povijest tehnike bio je elektrotehnički inženjer Vladimir Muljević, koji je od 1970-ih tomu području posvetio velik dio svojega opusa. U novije doba istraživači povijesti tehnike iz redova inženjera, ali i drugi, okupljaju se oko redovitih znanstvenih skupova, npr. Medunarodne konferencije o industrijskoj baštini u Rijeci (od 2010) ili Povijesti i filozofije tehnike u Zagrebu (od 2012). Ipak, i danas su rijetki nastavnici tehničkih fakulteta koji u nastavne programe svojih kolegija uvrštavaju povijesni pregled pojedinih tema u Hrvatskoj, samostalni kolegiji ili studiji o tome ne postoje, kao ni udruge ili tijela institucija koji bi okupljali malobrojne istraživače.

Posljedica navedenoga jest razmjerno oskudna literaturu koja opisuje povijest i današnje stanje tehnike, koja se uglavnom svodi na monografske prikaze rijetkih istaknutih osoba, fenomena i razdoblja, spomenice fakulteta ili poduzeća, dok su sintetska djela koja donose usustavljeni pregled tehnike u cijelosti rijetka. Među njima ističe se pregled tehničkih znanosti, tehnike i tehnologije, objavljen u dvosveščanome katalogu $u^{4}$ izložbe Znanost u Hrvata 1996. Pokušaj cjelovite sinteze sveobuhvatne hrvatske baštine, tako i tehničke, jest kapitalni projekt HAZU-a Hrvatska $i$ Europa: kultura, znanost $i$ umjetnost u pet svezaka, od kojih su 1997-2010. izišla prva

2 Izvor: Agencija za znanost i visoko obrazovanje (https://www.azvo.hr/hr/visoko-obrazovanje/ statistike?id=1122:broj-studenata-po-poljima-od-akademske-godine-2008-09-do-2012-13\&catid=442; pristupljeno 17. III. 2019)

3 Izvor: Statistički ljetopis 2017. Državni zavod za statistiku. Zagreb 2018. (https://www.dzs.hr/ Hrv_Eng/publication/2017/SI-1599.pdf; pristupljeno 17. III. 2019)

4 Znanost u Hrvata : Prirodoslovlje i njegova primjena (katalog izložbe). Zagreb 1996. 
četiri. Područje tehnike u razdoblju XVII-XIX. st. zasebno je u III. i IV. svesku obradio Vladimir Muljević. ${ }^{56}$

\section{Razvoj suvremene hrvatske enciklopedike i prva strukovna djela}

Važan korak prema usustavljenju spoznaja i sveobuhvatnom pristupu različitim područjima hrvatske nacionalne baštine, čak i ondje gdje su znanja o njima bila oskudna, jest razvoj suvremene hrvatske enciklopedike. Njezinim se utemeljiteljem smatra Mate Ujević7, koji je od 1939. bio pokretač i glavni urednik Hrvatske enciklopedije $^{8}$, opće enciklopedije s proširenom nacionalnom sastavnicom ${ }^{9}$ u prvotno zamišljenih 12 svezaka. Projekt je isprva pokrivao Konzorcij Hrvatska enciklopedija, a od 9. VIII. 1941. novoosnovani Hrvatski izdavalački (bibliografski) zavod (HIBZ), kojega je Ujević ujedno bio upravitelj. Prvi svezak Enciklopedije izišao je 1941., a peti (Dilatacija-Elektrika) 1945., kada je projekt prekinut. Kada je 9. V.1945. HIBZ preimenovan u Nakladni zavod Hrvatske, Ujević je u njemu bio gospodarski tajnik i tehnički urednik do 31. XII. 1945., kada je napustio tu instituciju. Rad na projektu Pomorskoga leksikona u četiri sveska enciklopedijskoga formata (poslije Pomorska enciklopedija), koji je, postavljanjem za urednika Petra Mardešića, Ujević inicirao u HIBZ-u, te objavljivanjem Primjeraka članaka Pomorskog leksikona ${ }^{10}$ 1944., Ujević je nastavio u Jadranskom institutu JAZU-a osnovanom 1948., kada je imenovan glavnim urednikom; 1949. objavio je Upute urednicima i suradnicima Pomorske enciklopedije ${ }^{11}$. Iz uputa je vidljivo da je Pomorska enciklopedija u najvećoj mjeri zasnovana na iskustvima i materijalu prikupljenome pri izradbi Hrvatske enciklopedije, pa otud i njezina svestranost svojstvena općim enciklopedijama i izražena nacionalna sastavnica.

Osnutkom Leksikografskoga zavoda FNRJ 1950. pod vodstvom Miroslava Krleže (danas Leksikografski zavod Miroslav Krleža), pokreću se projekti na tri ra-

5 V. Muljević: »Tehnika i tehničke znanosti«, Hrvatska $i$ Europa: kultura, znanost i umjetnost, sv. III. Barok i prosvjetiteljstvo (XVII.-XVIII. stoljeće). Zagreb 2003., str. 417-429.

6 V. Muljević: »Razvitak i stanje tehnike u Hrvatskoj u XIX. stoljeću«, Hrvatska $i$ Europa: kultura, znanost i umjetnost, sv. IV. Moderna hrvatska kultura od preporoda do moderne (XIX. stoljeće). Zagreb 2003., str. 779-785.

7 M. Švab: »Mate Ujević, utemeljitelj suvremene hrvatske enciklopedike«, Radovi Leksikografskoga zavoda »Miroslav Krleža«, 2(1992), str. 9-36.

8 Hrvatska enciklopedija, sv. 1-5. Zagreb 1941-45.

9 Ujević o tome piše u oglednom arku: »Želimo, da naša enciklopedija bude u prvom redu hrvatska, to jest da se posebno i opširnije obazire na hrvatske prilike, a zatim na prilike bližih, srodnih naroda, dok će prilike i osobine dalekih naroda prikazivati zbitije i sažetije.»

10 M. Ujević: Primjerci članaka Pomorskog leksikona. Zagreb 1944.

1 Pomorska enciklopedija, upute urednicima i suradnicima. Zagreb 1949. 
zine: općoj (Enciklopedija leksikografskog zavoda' ${ }^{12}$ ), nacionalnoj (Enciklopedija fugoslavije $\left.^{13}\right)$ i strukovnoj.

Kako su osnove projekta prethodno bile pripremljene, Pomorska enciklopedi$j a^{14}$ bila je prvo zavodsko enciklopedičko djelo. Prvo izdanje u osam svezaka izlazilo je 1954-64., a uredio ga je Mate Ujević, dok je drugo izdanje, također u osam svezaka, glavnih urednika Vladislava Brajkovića i Petra Mardešića izlazilo 1972-89. Iako je zbog pokrivenosti širega kulturno-povijesnoga kompleksa Enciklopedijom fugoslavije, odnosno Općom enciklopedijom, taj dio sažet, i dalje je egzistirao u Pomorskoj enciklopediji, osiguravajući njezinu sveobuhvatnost. Obraćajući se najširem čitateljstvu i nudeći šarolik izbor pojmova, Pomorska je enciklopedija, kao prethodnica početno zamišljenoga niza od deset strukovnih (posebnih) enciklopedija, ${ }^{15}$ jedno od najboljih zavodskih strukovnih izdanja: utemeljuje enciklopedijsko načelo sveobuhvatnosti, detaljno obrađujući opće pojmove, ali i nacionalnu sastavnicu u vidu biografija istaknutih osoba, prikaza poduzeća, ustanova i sl., u rasponu članaka od mikropedijskih do makropedijskih. $\mathrm{O}$ tome se govori u predgovoru 1. izdanju:

»Redakcija Pomorske enciklopedije, shvaćajući pomorstvo kao širok skup naučnih disciplina i praktičnih djelatnosti usmjerenih na iskorišćivanje mora, obuhvatila je u ovome djelu sve struke, koje su u užoj ili široj vezi s pomorstvom: biologiju, brodogradnju, opremu broda, ekonomiku pomorstva, etnologiju, geografiju, higijenu, meteorologiju, oceanografiju, pravo, historiju, historiju pomorskih ratova, ratnu mornaricu, unutrašnju plovidbu, ribarstvo i pomorsku terminologiju u 7 jezika (hrvatski ili srpski, engleski, francuski, njemački, ruski, španjolski i talijanski). Po obuhvatnosti materije, Pomorska enciklopedija se znatno razlikuje od sličnih djela u enciklopedijskoj literaturi: strana enciklopedijska djela ove vrsti prikazuju pomorstvo u najužem smislu - brodogradnju, opremu broda i iskorišćivanje broda. Potreba naših pomoraca za stručnom literaturom i želja da ovo djelo bude pristupačno širokom krugu čitača navela nas je na misao, da Pomorsku enciklopediju učinimo stručnom enciklopedijom, koja obuhvaća znatan dio materijala opće enciklopedije, ostajući uvijek u granicama pomorstva u širem smislu riječi«. ${ }^{16}$

Kao takva bila je uzor strukovnim enciklopedijama Zavoda koje su slijedile, što je, kako se poslije pokazalo, bilo teško dosegnuti.

12 Enciklopedija leksikografskog zavoda, I. izdanje, sv. 1-7. Zagreb 1955-64.

13 Enciklopedija fugoslavije, I. izdanje, sv. 1-8. Zagreb 1955-71.

14 Pomorska enciklopedija, I. izdanje, sv. 1-8. Zagreb 1954-64.

15 V. Muljević: »U povodu objavljivanja 13. završnog sveska Tehničke enciklopedije«, Hrvatski glasnik intelektualnog vlasništva, 4(1997) 5, str. 1791-1794.

16 Pomorska enciklopedija, 1. svezak. Zagreb 1954. 
Izvjesno je da je Ujević još prije dolaska u Zavod razmišljao o Leksikonu likovnih umjetnika, te ga pokrenuo dolaskom u Zavod pod nazivom Enciklopedija likovnih umjetnosti ${ }^{17}$, a u početnom su razdoblju zavodska strukovna izdanja bila i Medicinska enciklopedija ${ }^{18}$, Muzička enciklopedija ${ }^{19}$ i Šumarska enciklopedija ${ }^{20}$, koje su u većoj ili manjoj mjeri uspijevale slijediti koncepciju Pomorske enciklopedije, uvrštavajući i biografije istaknutih domaćih pojedinaca te obrađujući pojedine nacionalne teme, $u$ samostalnim člancima ili u sklopu većih, preglednih članaka. Među strukovnim enciklopedijama, projekti kojih su inicirani u početnome razdoblju LZ-a, bila je i Tehnička enciklopedija.

\section{Tehnička enciklopedija}

Tehnička enciklopedija ${ }^{21}$, koja je u 13 svezaka izlazila 1963-97., najopsežnije je enciklopedičko djelo na hrvatskome jeziku ikad priređeno. Obuhvaća 642 članka na ukupno 9500 stranica s 22000 ilustracija. U osnovi je zamišljena kao izvor znanja koji će školarcima i drugim zainteresiranima dati uvodni prikaz iz najširega područja tehnike. Međutim, prateći najnovija znanstvena dostignuća toga područja, svojedobno je u mnogo slučajeva predstavljala jedinu stručnu literaturu na hrvatskome jeziku, te je postupno prerasla u izvor na kojem su mnogi naraštaji inženjera gradili svoje obrazovanje.

Prema dokumentima iz arhive Leksikografskoga zavoda, 10. X. 1951., radi pokretanja Tehničke enciklopedije, održana je sjednica predstavnika LZ-a (Anđelko Malinar, Anton Koštre i Josip Terahaj), Društva arhitekata Hrvatske (Pavao Jušić), Društva agronoma NRH (Josip Kovačević), Tehničkoga fakulteta (Adam Armanda) i Društva inženjera i tehničara Hrvatske (Emil Brajković) - Sekcija strojara (Branko Šimunić), Sekcija tekstilaca (Mladen Žerdik), Sekcija kemičara (Mirko Mirnik), Sekcija građevinara (Ljudevit Tomičić), Sekcija električara (Vladimir Muljević), Sekcija rudara i metalurga (Oskar Roboz) i Sekcija geodeta (Mato Janković). Na tom je sastanku odlučeno da će Tehnička enciklopedija obuhvatiti »suvremeno stanje tehničkih nauka i razvoj tehnike uopće, a napose kod nas, biografije domaćih i stranih stručnjaka, ustanova i t. d.«.

Godine 1952. sastavljen je Redakcioni odbor za izradu alfabetarskih jedinica, kojim je uime Zavoda koordinirao leksikograf Anđelko Malinar. Prema internim

17 Enciklopedija likovnih umjetnosti, sv. 1-4. Zagreb 1959-66.

18 Medicinska enciklopedija, I. izdanje, sv. 1-10. Zagreb 1957-65.

19 Muzička enciklopedija, I. izdanje, sv. 1-2. Zagreb 1958-63.

20 Šumarska enciklopedija, I. izdanje, sv. 1-2. Zagreb 1959-63.

${ }_{21}$ Tehnička enciklopedija, sv. 1-13. Zagreb 1963-97. 
Uputama za izradivanje alfabetarskih jedinica iz iste godine, opseg Tehnicke enciklopedije trebao je biti šest svezaka po 800 stranica (jedna stranica trebala je obuhvatiti 160 redaka po 60 znakova u retku), u što je bilo uključeno i $25 \%$ prostora za ilustracije. Građa enciklopedije bila je podijeljena u osam područja, a predviđeni raspored opsega po područjima prikazan je u tablici 1 .

Tablica 1. Predviđeni raspored opsega TE prema Uputama za izradivanje alfabetarskih jedinica iz 1952.

\begin{tabular}{|l|l|l|l|l|l|l|}
\hline & Područje & Str. & Udio & Redaktori & Koordinatori & LZ \\
\hline I & Arhitektura & 720 & $15 \%$ & Vlado Antolić & \\
\hline II & Geodezija & 480 & $10 \%$ & Mato Janković & Pavao Jušić & \\
\hline III & Građevinarstvo & 720 & $15 \%$ & Ljudevit Tomičić & & \\
\hline IV & Elektrotehnika & 600 & $12,5 \%$ & Hrvoje Požar & Vladimir & Anđelko \\
\hline V & Strojarstvo & 600 & $12,5 \%$ & Branko Šimunić & Muljević & Malinar \\
\hline VI & Rudarstvo & 600 & $12,5 \%$ & Petar Kisić & & \\
\hline VII & Kemija & 600 & $12,5 \%$ & Dragutin Kolbach & Oskar \\
VIII & Tekstil & 480 & $10 \%$ & Mihajlo & Roboz & \\
& & & & Friedländer & & \\
\hline
\end{tabular}

Prema istim Uputama, na kraju Enciklopedije trebao je biti »indeks svih osnovnih, širih i užih pojmova, lica i stvari«. Prema internom Materijalu za izradbu alfabetara $T E$ iz 1952., evidentno je da je bilo predviđeno određeni dio enciklopedijske građe posvetiti povijesti i tadašnjem stanju tehnike, napose u tadašnjoj državi FNRJ, i to uglavnom kroz različite oblike pregleda struke, znanosti, inovacija i dostignuća, te osoba, organizacija, škola, instituta, knjiga, časopisa. Potpodručja pojedinih struka vezana uz tu tematiku, njihov opseg i udio $u$ cjelokupnom opsegu pojedine struke prikazan je u tablici 2. 
Tablica 2. Udio u opsegu pojedinih struka predviđen za prikaz njihova razvoja u zemlji i svijetu

\begin{tabular}{|c|c|c|c|}
\hline Područje & Potpodručje & Str. & $\begin{array}{l}\text { Udio u opsegu } \\
\text { struke }\end{array}$ \\
\hline \multirow{5}{*}{ Arhitektura } & $\begin{array}{l}\text { Sadašnje stanje arhitektonske nauke: škole, } \\
\text { instituti i dr. u FNRJ }\end{array}$ & \multirow{5}{*}{108} & \multirow{5}{*}{$15 \%$} \\
\hline & Časopisi i knjige & & \\
\hline & Arhitektonsko nasljeđe & & \\
\hline & Ostvarenje projekata u periodu od oslobođenja & & \\
\hline & $\begin{array}{l}\text { Ličnosti koje su pridonijele razvoju nauke i } \\
\text { prakse }\end{array}$ & & \\
\hline \multirow{3}{*}{ Geodezija } & Bibliografija & \multirow{3}{*}{80} & \multirow{3}{*}{$16,7 \%$} \\
\hline & $\begin{array}{l}\text { Historijski pregled radova na državnom } \\
\text { premjeru i katastru na području FNRJ }\end{array}$ & & \\
\hline & Ličnosti i organizacije & & \\
\hline \multirow{5}{*}{ Građevinarstvo } & Historija građevinarstva & \multirow{5}{*}{18} & \multirow{5}{*}{$2,5 \%$} \\
\hline & Sadašnje stanje nauke, škole, instituti & & \\
\hline & Časopisi, knjige & & \\
\hline & Građevinsko nasljeđe & & \\
\hline & $\begin{array}{l}\text { Ličnosti koje su pridonijele razvoju nauke i } \\
\text { prakse }\end{array}$ & & \\
\hline \multirow{4}{*}{ Elektrotehnika } & Razvoj nauke i prakse & \multirow{4}{*}{15} & \multirow{4}{*}{$2,4 \%$} \\
\hline & Ostvarenja i inovatorstvo u FNRJ & & \\
\hline & Ličnosti & & \\
\hline & Škole, instituti, publikacije & & \\
\hline \multirow{5}{*}{ Strojarstvo } & Razvoj nauke i prakse & \multirow{5}{*}{40} & \multirow{5}{*}{$6,3 \%$} \\
\hline & Ostvarenja u FNRJ & & \\
\hline & Ličnosti u razvoju tehnike & & \\
\hline & Sadašnje stanje nauke & & \\
\hline & Literatura & & \\
\hline \multirow{6}{*}{ Rudarstvo } & Historija rudarstva FNRJ & \multirow{6}{*}{26} & \multirow{6}{*}{$4,3 \%$} \\
\hline & Razvoj nauke i prakse & & \\
\hline & Ostvarenja u FNRJ & & \\
\hline & $\begin{array}{l}\text { Ličnosti koje su u prošlosti i sadašnjosti } \\
\text { pridonijele razvoju }\end{array}$ & & \\
\hline & Sadašnje stanje nauke, škole i instituti & & \\
\hline & Knjige i časopisi & & \\
\hline
\end{tabular}




\begin{tabular}{|c|c|c|c|}
\hline \multirow{6}{*}{ Kemija } & Historijski podaci iz FNRJ & \multirow{6}{*}{65} & \multirow{6}{*}{$11 \%$} \\
\hline & Razvoj nauke i prakse & & \\
\hline & Ostvarenja, inovatorstvo i dr. u FNRJ & & \\
\hline & $\begin{array}{l}\text { Ličnosti koje su u prošlosti i sadašnjosti } \\
\text { pridonijele razvoju nauke i ostvarenjima }\end{array}$ & & \\
\hline & Sadašnje stanje nauke: škole, instituti & & \\
\hline & Knjige i časopisi & & \\
\hline \multirow{4}{*}{ Tekstil } & Razvoj nauke i prakse & \multirow{4}{*}{32} & \multirow{4}{*}{$6,7 \%$} \\
\hline & Ostvarenja, inovatorstvo & & \\
\hline & Ličnosti koje su pridonijele i pridonose razvitku & & \\
\hline & Sadašnje stanje nauke, škole instituti & & \\
\hline Ukupno & & 384 & \\
\hline
\end{tabular}

Iz tablice je vidliivo da su u preliminarnoj fazi priprema za izradbu abecedarija u tom segmentu bile predviđene 384 stranice ( $8 \%$ ukupnoga opsega Enciklopedije), tj. gotovo polovica jednoga sveska.

Prema anketi o pokretanju i obliku Tehničke enciklopedije koju je u prosincu 1952. proveo Zavod, poslanoj na 50-ak mjerodavnih institucija tadašnje Jugoslavije, uglavnom odjelima svih tehničkih fakulteta u zemlji, anketirani su se uglavnom pohvalno izražavali o inicijativi, a većina anketiranih predložila je da se enciklopedija organizira u osam svezaka, koliko je bilo predviđenih područja, te da svaki svezak obrađuje jedno područje.

Nakon 1952., usmjeravanjem zavodskih snaga prema drugim projektima, rad je na Enciklopediji zamro, te je ponovno pokrenut 1955. imenovanjem inženjera kemijske tehnologije i profesora na Tehnološkome fakultetu Rikarda Podhorskog za glavnoga urednika te Osnivačkom skupštinom Redakcije Tehničke enciklopedije 1956. U pripremama za ponovno pokretanje projekta, osnovna je koncepcija izmijenjena te su, za razliku od drugih zavodskih strukovnih enciklopedija koje su joj prethodile, u $T E$ izostale biografije, dok je nacionalna sastavnica obrađena tek sporadično.

Među većim brojem radova o povijesti, važnosti i pojedinim izvedbenim aspektima $T E$, osobito se ističe rad R. Marušića posvećen početcima toga projekta, razvoju koncepcije i sastavljanju abecedarija ${ }^{22}$, te sustavni prikaz razvoja projekta $\mathrm{i}$ zasada Tehničke enciklopedije Z. Jakobovića ${ }^{23}$.

${ }^{22}$ R. Marušić: »Prilozi za historijat tehničke enciklopedije. Činjenice i sjećanja«, Radovi Leksikografskog zavoda Miroslav Krleža, 6(1997), str. 75-90.

${ }^{23}$ Z. Jakobović: »Pothvat Tehničke enciklopedije«, Radovi Leksikografskog zavoda Miroslav Krle ža, 10(2001), str. 121-130. 
U oba se rada autori dotiču i pitanja izostanka obradbe povijesti tehnike i njezine nacionalne sastavnice, napose putem biografija zaslužnih, pa se u potonjem posebno ističe:

»Na početcima je zamišljeno da Tehnička enciklopedija donosi i biografije znanstvenika, izumitelja i svih koji su pridonijeli razvoju tehnike, bivših i živih, iz svijeta i iz zemlje. Od toga se odustalo već pri pripremanju prvoga sveska, dijelom zbog nedostatka povijesti tehnike u zemlji, a dijelom i zbog teškoća u priznavanju prvenstva izuma i drugih stručnih i tehničkih dostignuća. Ta su prvenstva uvijek bila predmetom ne samo nacionalnog, nego $i$ političkog, a u ona vremena i ideološkog nadmetanja. Stoga je već prvo uredništvo izostavljanjem biografija izbjeglo rasprave o tomu tko je što izumio, a osobito rasprave o tome koji su zaslužni živi stručnjaci uvršteni, a koji nisu, te što im se navodi u životopisu.«

Na početnim sastancima kolegija $T E$ već se 1956-57. raspravljalo o biografijama, kada je prevladavao stav kako se treba ograničiti samo na one najvažnije, opravdavajući to činjenicom »da će Enciklopedija Jugoslavije obraditi sve naše ljude « ${ }^{24}$. Ipak, poslije se uvidjelo da to nije slučaj, ali se uredništvo $T E$ ipak nije odlučilo za biografije, ostajući svjesno toga manjka. Stoga je u uvodnoj riječi u 1. svesku $T E$ iz 1963. glavni urednik R. Podhorsky napisao:

»Za razliku od drugih stručnih enciklopedija Jugoslavenskog leksikografskog zavoda, Tehnička enciklopedija ne sadržava biografije. To nije zbog toga što ni enciklopedije i leksikoni tehnike na drugim jezicima takvih biografija redovito ne donose, nego je to odraz zaostalosti historije tehnike kao naučne grane u našoj zemlji. Postoji namjera da se indeks imena na kraju djela dopuni biografskim podacima i time nadoknadi taj u sadašnjem momentu i pod datim okolnostima neizbježni manjak. $\ll^{25}$

Međutim, ideja o indeksu imena s biografskim podatcima nije realizirana i 13. je svezak Enciklopedije izašao 1997. s indeksom, ali bez osoba i njihovih biografskih podataka.

U međuvremenu, svesci Enciklopedije izlazili su uglavnom kontinuirano, u prosjeku svake tri godine, što je, usprkos tadašnjem nezadovoljstvu stručne javnosti, čak i za današnje prilike bilo vrlo agilno. Podhorsky je uredio prva četiri sveska (objavljena 1963., 1966., 1969., 1973), 1975. na mjestu glavnoga urednika nakratko ga je kao vršitelj dužnosti zamijenio leksikograf Živan Viličić, koji je dovršio rad i na petome svesku.

${ }^{24}$ R. Marušić: »Prilozi za historijat tehničke enciklopedije. Činjenice i sjećanja«, Radovi Leksikografskog zavoda Miroslav Krleža, 6(1997), str. 75-90.

25 Tehnička enciklopedija, sv. 1. Zagreb 1963. 
Terniosta encipeopetija

Oreacti

\section{(TE)}

$$
\begin{aligned}
& \text { ofent } I, I, \text { III } \\
& \text { grupe } A, B, C \\
& \text { strake } 1,2, B \\
& \text { grene } 2, B, C
\end{aligned}
$$

$15 \%$ $720 \mathrm{tr}$.

$10 \%$ 480 th. $15 \%$ 720 tr. $12.5 \%$ $600 t_{+}$.

12. $5 \%$ 600 is $12.5 \%$ $600 \mathrm{tar}$

VI. Stamy12. $5 \%$ $600 \mathrm{ct}$.

VIII. Terstie $10 \%$ $480 \mathrm{st}$. $100 \%$ $4.800 \mathrm{str}$

4. $800 x_{r}=6$ trezes + Indeps 


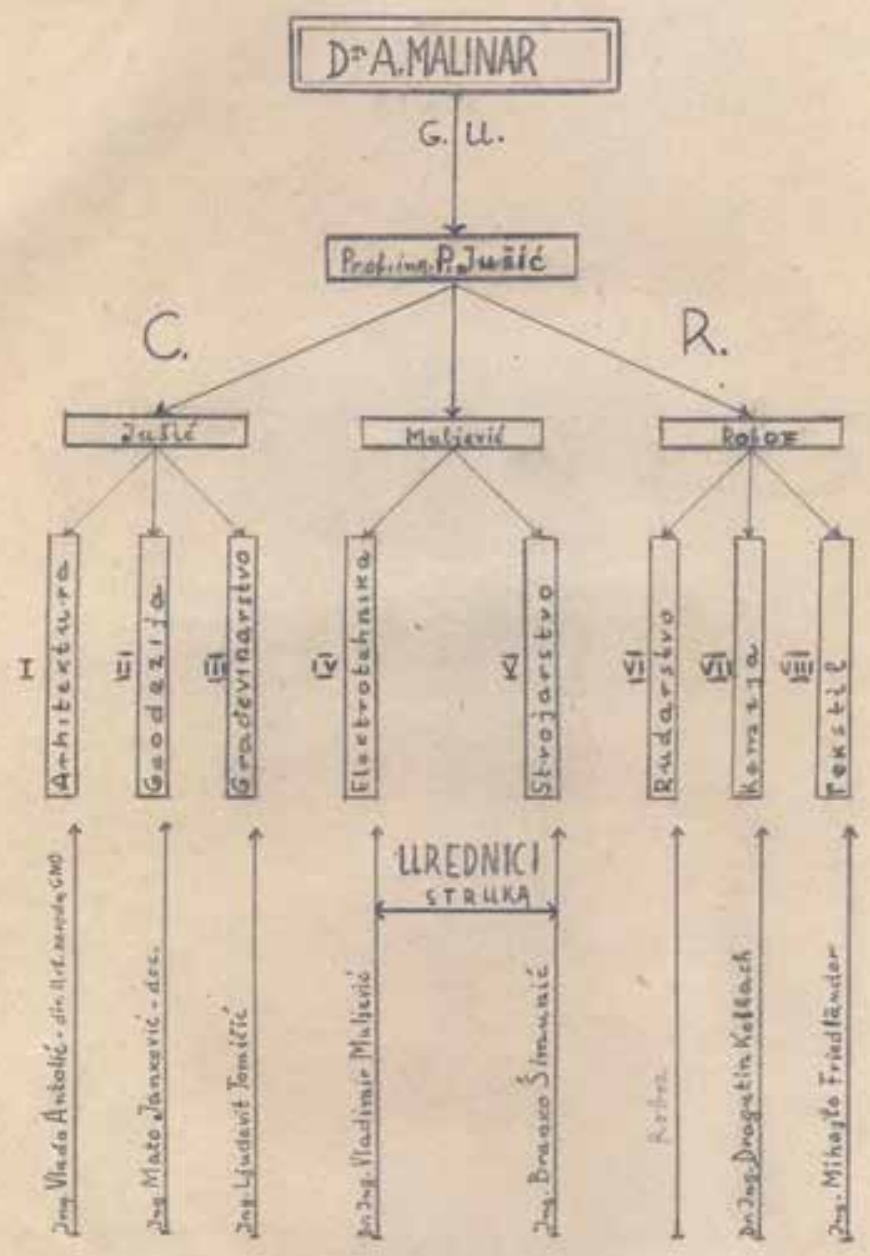

Dio »Uputa za izrađivanje alfabetarskih jedinica« Tehničke enciklopedije iz 1952. 
Godine 1976. za glavnoga je urednika imenovan akademik Hrvoje Požar, glavni tajnik Akademije, koji je uredio sljedećih sedam svezaka, od 6. sv. (1979) do 12. sv. (1992). Tijekom 1991. zamijenio ga je leksikograf Duško Štefanović, koji je kao glavni urednik uredio i 13. sv. (1997).

U konačnici se $T E$ afirmirala kao skup razmjerno maloga broja vrlo velikih članaka, koji su u osnovi predstavljali usustavljene i enciklopedički obrađene materijale pojedinih kolegija ili njihovih dijelova koje su autori predavali na tehničkim fakultetima. U tome je i glavna važnost $T E$, koja je u oskudici visokoškolskih udžbenika iz područja tehničkih znanosti dugo bila jedina literatura. Usprkos današnjemu gotovo eksponencijalnom rastu znanstvenih spoznaja, naročito izraženih u tehničkim znanostima, zahvaljujući osnovnoj usmjerenosti $T E$ teorijskim i tehničkim osnovama pojedinih područja, velik broj članaka u $T E$ i danas je aktualan i rabi se kao obvezna literatura visokoškolskih kurikuluma.

Povijesni, kulturni, gospodarski i sl. aspekti pojedinih pojmova, među koje spada i nacionalna sastavnica (raširenost, industrija i sl.), od prvoga se sveska u TE obrađuju na početku članaka (iza kratka uvoda), vizualno odijeljeni od ostatka članka manjom veličinom slova. Evidentno je nastojanje da svaki članak bude popraćen takvim opisima, no oni nerijetko izostaju zbog prirode pojma koji se obrađuje, a kadšto za to nema opravdanja, pa se nesumnjivo radi o nedostatku podataka pri oblikovanju članka. Većinom su ti opisi razmjerno kratki u usporedbi s ostatkom članka, posvećeni razvoju u svijetu (npr. Aluminijum, Astronomija, Avion, Aerodrom, Brodogradnja, Cesta, Člik, Fotografija, Geodezija, Kemija, Keramika, Lakovi i boje, Računala, Rashladna tehnika), a samo je u ponekim člancima obrađena i nacionalna sastavnica (Automobilna vozila, Brana, Elektroprivreda i elektroindustrija, Fedrilica, zračna, Promet, javni gradski), koja tek iznimno donosi temeljitiji pregled (Papir, Rudarstvo).

U posljednjem svesku zapaža se promjena: veći je broj članaka opremljen više ili manje iscrpnim opisima, koji najčešće donose i prikaz situacije u Hrvatskoj (Teorija elastičnosti, Tkanje, Tunel, Turbina, vodna, Uspinjača, Željeznica).

\section{Hrvatska tehnička baština, Enciklopedija fugoslavije i Enciklopedija leksikografskog zavoda}

Kako je navedeno, isprva se očekivalo da će izostanak nacionalnih tema u Tehničkoj enciklopediji, napose biografija, biti nadoknađen u drugim zavodskim djelima, poglavito Enciklopediji fugoslavije.

Enciklopedija fugoslavije, zamišljena kao temeljno djelo LZ-a, nacionalna je enciklopedija, koje je prvo izdanje glavnoga urednika Miroslava Krleže izlazilo 
1955-71. u osam svezaka, dok je drugo izdanje predviđeno u čak 68 svezaka (po šest sadržajno identičnih izdanja na hrvatskome ili srpskome - latinično i ćirilično, makedonskome, slovenskome, albanskome i madžarskome, u devet osnovnih i jednome dopunskome svesku, te dva sveska na engleskome); do prekida projekta 1990. na hrvatskom je jeziku izašlo šest osnovnih svezaka. Rad na tom velikom projektu već je u prvome izdanju bio organiziran u nekoliko redakcija (središnja, republičke). Urednik iz područja tehnike za Hrvatsku u prvome je izdanju bio R. Podhorsky, a u drugome akademici Ivan Jurković, Andre Mohorovičić, Vilim Niče i Hrvoje Požar.

Usprkos ambiciozno zamišljenom projektu, od velikana domaće tehnike biografskim člancima obrađeni su samo iznimni: u prvome izdanju Bošnjaković, Hanaman, Lupis, Tesla i Vrančić, ali ne i npr. Armanda, Bazjanac, Karšulin, Penkala, Schwarz, Sorta ili Stipetić, što se donekle počelo ispravljati u drugome izdanju, u kojem je i dalje zastupljen samo mali broj tehničara. Osim toga, u prvome je izdanju nacionalnoj sastavnici tehnike posvećen određeni broj članaka koji opisuju opće tehničke pojmove (ambalaža; amonijačna soda; auto-saobraćaj; avijacija, civilna; brodogradnja; elektrifikacija i elektroprivreda; elektroindustrija; hemijska industrija; graficka industrija; mašinogradnja), dok u drugome izdanju takvih članaka nema; u njemu se tehnika javlja jedino u dijelovima članaka o pojedinim republikama posvećenim njihovim gospodarstvima, kojih ima i u prvome izdanju. O pojedinim tehničkim znanostima (npr. gradevinarstvo, elektrotehnika) ni u jednom izdanju nema spomena, a među člancima sporadično se javljaju oni koji obrađuju pojedina poduzeća (Brodospas, 1. izdanje) ili institucije (Brodarski institut, 2. izdanje).

Enciklopedija leksikografskog zavoda ${ }^{26}$, kao opća enciklopedija i još jedno temeljno izdanje iz doba zavodskih početaka, koja je za razliku od Enciklopedije fugoslavije usmjerena svesvjetskim temama, u još manjoj mjeri donosi nacionalnu sastavnicu tehnike i biografije zaslužnika. Prvo izdanje izišlo je u sedam svezaka (1955-64), drugo u šest svezaka (1966-69), a naslijedila ih je Opća enciklopedija ${ }^{27}$ glavnoga urednika Josipa Šentije u devet svezaka (1977-88).

Prisutnost biografija odabranih velikana hrvatske tehnike u nekima od ranih hrvatskih enciklopedičkih djela prikazana je u tablici 3.

${ }^{26}$ Enciklopedija leksikografskog zavoda, I. izdanje, sv. 1-7, Zagreb 1955-64; II. izdanje, sv. 1-6, Zagreb 1966-69.

27 Opća enciklopedija, sv. 1-9. Zagreb 1977-88. 
Tablica 3. Prisutnost biografija odabranih važnih osoba za razvoj hrvatske tehnike u pojedinim enciklopedičkim djelima ${ }^{28}$

\begin{tabular}{|c|c|c|c|c|c|c|}
\hline & $\begin{array}{l}\text { Hrvatska } \\
\text { enciklope- } \\
\text { dija }\end{array}$ & $\begin{array}{l}\text { Enciklopedi- } \\
\text { ja fugoslavi- } \\
\text { je, 1. izdanje }\end{array}$ & $\begin{array}{l}\text { Enciklopedi- } \\
\text { ja fugoslavi- } \\
\text { je, 2. izdanje }\end{array}$ & $\begin{array}{l}\text { Enciklope- } \\
\text { dija LZ-a, } \\
\text { 1. izdanje }\end{array}$ & $\begin{array}{l}\text { Enciklope- } \\
\text { dija LZ-a, } \\
\text { 2. izdanje }\end{array}$ & $\begin{array}{l}\text { Opća } \\
\text { enciklo- } \\
\text { pedija }\end{array}$ \\
\hline Armanda & & & + & & & \\
\hline Alačević & + & + & + & + & + & + \\
\hline \multicolumn{7}{|l|}{ Bazjanac } \\
\hline Blanuša & & + & + & + & + & + \\
\hline Bošnjaković & + & + & + & + & + & + \\
\hline Budicki & + & & + & & & \\
\hline Degen & + & & & & & \\
\hline
\end{tabular}

\section{Tehnika i novija hrvatska enciklopedička djela}

Prvi među zavodskim izdanjima sustavnu obradbu biografija istaknutih osoba hrvatske tehnike donosi projekt Hrvatskoga biografskoga leksikona $(H B L)^{29}$, koji je još 1975. u složenim društvenim uvjetima pokrenuo Miroslav Krleža. To je trajan, dugoročan i opsežan leksikografski biobibliografski projekt, svojevrsna nacionalna biografska enciklopedija, koja sadržava životopise Hrvata koji su ostavili znatan trag u svojoj zemlji i svijetu te pripadnika drugih naroda koji su sudjelovali u životu hrvatskih zemalja. Dosad je objavljeno osam svezaka tiskanoga izdanja (A-Li) s ukupno 11423 članka; glavni urednik prvoga sveska (1983) bio je Nikica Kolumbić, drugoga (1989) Aleksandar Stipčević, trećega do osmoga Trpimir Macan (1993-2013); od 2014. glavni je urednik Nikša Lučić. Od 2009. u mrežnom je obliku ${ }^{30}$ dostupan dio članaka, a od 2015. svi članci tiskanoga izdanja te neke biografije osobito važnih osoba iz budućih tiskanih svezaka. U leksikonu je područje tehnike obrađeno vrlo sustavno i detaljno, te često predstavlja jedini izvor informacija o nekim osobama. Ipak, taj je dugoročan projekt do 2019. obradio nešto više od polovice abecede, a u obzir uzima samo osobe rođene do 1945 (u mrežnom izdanju obrađeni su i neki pojedinci rođeni nakon te godine), pa su neki od današnjih istaknutih pojedinaca iz područja tehnike iz toga razloga zasad neobrađeni. Osamostaljenjem Hrvatske 1991., javljaju se i druga enciklopedička izdanja koja u znatnoj mjeri obrađuju hrvatsku nacionalnu sastavnicu.

28 Armanda, Adam, brodograđevni inženjer, 1898-1958; Alačević, Jerko, geodet, 1876-1963; Bazjanac, Davorin, inženjer strojarstva, 1902-88; Blanuša, Danilo, matematičar i fizičar, 1903-87; Bošnjaković, Fran, inženjer strojarstva, 1902-93; Budicki, Ferdinand, pionir automobilizma, biciklizma i zrakoplovstva, 1871-1951; Degen, Henrik, ljevač zvona, 1801-61.

${ }^{29}$ Hrvatski biografski leksikon, sv. 1-8 (A-Li). Zagreb 1983-2013.

30 Hrvatski biografski leksikon. Zagreb 2009. (http://hbl.lzmk.hr/; pristupljeno 19. III. 2019) 
Usporedno s pripremama za izdanje hrvatske nacionalne enciklopedije, koje su se u LZ-u vodile 1990-ih, u suradnji s tom institucijom nacionalnu je građu u sažetom obliku (u dva sveska) donio Hrvatski leksikon ${ }^{31}$ 1996-97. Prema radu M. Klemenčića, ${ }^{32}$ Hrvatski leksikon glavnoga urednika Antuna Vujića enciklopedijski je pregled isključivo nacionalne građe, objavljen u izdanju Naklade Leksikon 1996 (prvi svezak A-L), odnosno 1997 (drugi svezak M-Ž). Riječ je o prvome leksikografskom djelu nacionalnoga tipa u kojem je pozornost pridana isključivo građi relevantnoj za hrvatski nacionalni korpus i kulturu. $U$ tom se djelu, gotovo prvi put u nas, nizom manjih članaka sustavno obrađuje nacionalna sastavnica za mnoga područja tehnike: djelatnosti i discipline (brodogradnja, strojogradnja, strojarstvo), uže djelatnosti i opći tehnički pojmovi (akvedukt, alkemija, argosy, arsenal, pomorski, brod, proizvodnja i prerada kovina, cestovni promet), znatan broj biografija osoba (Abakumov, Adamić, Alfirević, Andročec, Bazjanac), poduzeća (fugoturbina - ABB, ACY, Tvornica duhana Rovinj, Uljanik), institucije (Brodarski institut), časopisi (ABC tehnike, Acta adriatica), udruge (Hrvatsko kemijsko drusttvo) i dr.

Istodobno se u Zavodu odustalo od posve nacionalne enciklopedije, te je donesena odluka o izradbi opće enciklopedije s pojačanom nacionalnom sastavnicom, Hrvatske enciklopedije ${ }^{33,34} \mathrm{u} 11$ svezaka (1999-2009). Glavni urednici bili su akademik Dalibor Brozović (1-3. svezak), August Kovačec (4-7. svezak) i Slaven Ravlić (8-11. svezak). Godine 2013. pokrenuto je slobodno dostupno mrežno izdanje enciklopedije glavnoga urednika S. Ravlića, zasnovano na tiskanom izdanju, ali dopunjeno novim člancima, koje se stalno ažurira. Iz predgovora 1. svesku Hrvatske enciklopedije ${ }^{35}$.

》Osim općih znanja Hrvatska enciklopedija želi dati potpun i pouzdan prikaz hrvatske povijesti i kulture, geopolitičkoga smještaja, prirodnih bogatstava i prirodnih ljepota Hrvatske, njezinih zemljopisnih obilježja i njezina gospodarstva... Hrvatska enciklopedija bit ce dakle pouzdan izvor svih mogućih podataka o Hrvatskoj i o Hrvatima... Sve to drugim riječima znači da je Hrvatska enciklopedija u svojoj biti općom enciklopedijom, ali s pojačanom nacionalnom sastavnicom«.

U tome pogledu ona nastavlja tradiciju Ujevićeve Hrvatske enciklopedije. Procjenjuje se kako je oko 30\% prostora posvećeno nacionalnoj građi, a oko 70\% sveopćemu pojmovniku i Zemlje i svemira. Zadržavajući karakter dotadašnjih zavodskih općih en-

31 Hrvatski leksikon, sv. 1-2. Zagreb 1996-97.

32 M. Klemenčić: »Dvije nacionalne enciklopedije«, Studia lexicographica, 2(2008) 2, str. 27-37.

33 Hrvatska enciklopedija, sv. 1-11. Zagreb 1999-2009.

34 I. Starčević Stančić, C. Kraus: »Hrvatska enciklopedija - od tiskanoga do mrežnog izdanja«. Studia lexicographica, 8(2014) 1, str. 99-116.

35 Hrvatska enciklopedija, 1. svezak. Zagreb 1999. 
ciklopedija, članci Hrvatske enciklopedije razmjerno su koncizni i rijetko prelaze stotinjak redaka, a proporcionalan tomu je i opseg dijelova članaka posvećenih hrvatskoj sastavnici. Međutim, ostaje činjenica kako je Hrvatska enciklopedija jedno od prvih enciklopedičkih djela koja donose sustavnu obradbu hrvatske tehnike, makar u konciznu obliku.

Među tehničkim strukama, struka strojarstvo jedna je od najvećih u Hrvatskoj enciklopediji, te ju se može smatrati referentnom s obzirom na udjel nacionalne građe (npr. struke brodogradnja i promet u tom su pogledu nešto opsežnije, za razliku od astronautike ili zrakoplovstva). Od ukupno 480 članaka i 13333 retka, nacionalnu sastavnicu ima 79 članaka (16\%) s 1686 redaka (12\%). Među njima je 28 članaka koji obrađuju opće tehničke pojmove (aditivna proizvodnja, alatni strojevi, automobil, električna vozila, Kaplanova turbina, kombajn, lokomotiva, ljevarstvo, mlin, motokultivator, motorni vlak, naftovod, Peltonova turbina, polimerni materijali, protupožarna zaštita, strojarstvo, šivaći stroj, tehnika, toplana, traktor, tramvaj, trolejbus, uspinjača, vatrogastvo, vjetroelektrana, vodenica, vodomjer, žičara), od kojih je najveći dio opsega posvećen Hrvatskoj u člancima strojarstvo (43\%) i tehnika (57\%). Nacionalnoj sastavnici može se pripisati 49 biografija (Alfirević, Bazjanac, Beara, Bonačić Mandinić, Boncelj, Bošnjaković, Brlek, Brnić, Čatić, Deželić, Đurašević, Grubišić, Heim, Dragutin Horvat, Oto Horvat, Hribar, fecić, Katalinić, Katavić, Kolin, Kostelić, Kreuh, Krpan, Kuljanić, Kunstelj, Liščić, Lončar, Majcen, Malešević, Mandl, Mikuličić, Miler, Muftić, Penkala, Prejac, Raos, Ressel, Ruzskij, Salcher, Serdar, Sorić, Stupnišek, Šahnazarov, Šurina, Taboršak, Virag, Vrančić, Zdenković, Zgaga), od kojih su opsegom najveći Vrančić (146 redaka) i Penkala (52 retka), te jedan muzej (Tehnički muzej »Nikola Tesla«) i jedan časopis (Strojarstvo). Od strojograđevnih poduzeća (sva su obrađena u sklopu struke ekonomija) obrađena su samo ona najveća i poneko uspješno novije (Đuro Đaković Holding, Fugoturbina, Prvomajska, Rimac Automobili, TŽV Gredelj, Željezara Sisak).

U tablici 4. usporedni je prikaz biografija istaknutih strojarskih inženjera (A-B) u nekoliko novijih hrvatskih enciklopedijskih djela. Pri sastavljanju se rukovodilo Hrvatskim osobnikom, internom zavodskom bazom podataka u vidu tezaurusa, koja sadržava metapodatke o osobama koje se detektiralo proučavanjem 224 različita izvora. Na referentnom uzorku približnom prvoj polovici abecede (A-Li), koji obuhvaća 150 strojarskih inženjera, Hrvatski osobnik obradio je njih 142, Hrvatski biografski leksikon (HBL)67, Hrvatski leksikon (HL) 28, Hrvatska enciklopedija (HE) 24, a Hrvatska tehnička enciklopedija (HTE) 65. 

enciklopedičkih djela

\begin{tabular}{|c|c|c|c|c|c|c|}
\hline Osoba & 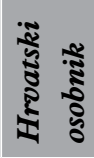 & ָֻ & $\mathbb{J}$ & $\mathbb{X}$ & $\stackrel{1}{1}$ & Rođen \\
\hline AGIĆ, Ante & + & & & & & 10. IV. 1951. \\
\hline ABDULI, Ramiz & & & & & + & 23. III. 1928. \\
\hline ALFIREVIĆ, Ivo & + & + & + & + & + & 28. VI. 1939. \\
\hline ANDRASSY, Mladen & + & & & & + & 4. VIII. 1947. \\
\hline ANTIĆ, Stanislav & + & & & & & o. 1930. \\
\hline ANTONIĆ, Radovan & + & & & & & 10. VI. 2016. \\
\hline ANZULOVIĆ, Boris & & & & & + & 25. X. 1947. \\
\hline BABIĆ, Darko & + & & & & & 30. VI. 1948. \\
\hline BAJIĆ, Dražen & + & & & & & 4. VIII. 1965. \\
\hline BANOVAC, Mladen & + & + & & & & 23. III. 1911. \\
\hline BARBIR, Frano & & & & & + & 21. XI. 1954. \\
\hline BARIŠIĆ, Branimir & + & & & & & 19. V. 1969. \\
\hline BARLE, Jani & + & & & & & 5. I. 1964. \\
\hline BAŠIĆ, Petar Frano & + & & & & & 4. X. 1945. \\
\hline BAZIJANAC, Ernest & + & & & & & 10. XI. 1953. \\
\hline BAZJANAC, Davorin & + & + & + & + & + & 22. IX. 1902. \\
\hline BEARA, Ljubomir & + & + & + & + & + & 12. X. 1925. \\
\hline BENDELJA, Božo & + & + & & & + & 17. XI. 1913. \\
\hline BILIĆ, Boženko & + & & & & & 5. XII. 1962. \\
\hline BILJAN, Mirko & + & & & & & 3. II. 1911. \\
\hline BJELOVUČIĆ, Dražen & + & + & + & & + & 14. IX. 1930. \\
\hline BOGDAN, Željko & + & & & & + & 15. X. 1949 . \\
\hline $\begin{array}{l}\text { BONAČIĆ MANDINIĆ, } \\
\text { Zoran }\end{array}$ & + & + & + & + & + & 27. II. 1933. \\
\hline BONCELJ, Josip & + & & + & + & + & 17. VII. 1889. \\
\hline BORAS, Berislav & + & + & & & & 23. IV. 1928. \\
\hline BORAS, Kazimir & + & & & & & o. 1910. \\
\hline BRNIĆ, Josip & + & & & + & + & 31. III. 1951. \\
\hline BUBAŠ, Marko & + & & & & & 8. III. 1944. \\
\hline
\end{tabular}




\begin{tabular}{|l|l|l|l|l|}
\hline BUDIĆ, Ivan & + & & & 18. XI. 1948. \\
\hline BUKLJAŠ, Zdravko & + & & & 18. X. 1941. \\
\hline BULJAN, Rudolf & + & + & + & 17. XII. 1925. \\
\hline BUTKOVIĆ, Mirko & + & + & + & 21. IX. 1936. \\
\hline
\end{tabular}

\section{Tehnički leksikon}

Usprkos tomu što je Tehnička enciklopedija bila dobro primljena u stručnoj javnosti te je postigla znatne uspjehe po broju prodanih primjeraka, Zavod i uredništvo $T E$ već su sredinom 1970-ih razmišljali o pokretanju Tehničkoga leksikona (Male tehničke enciklopedije) u šest svezaka, s približno 30000 članaka, sazdanoga na kazalu pojmova Tehničke enciklopedije. U elaboratu O pripremi za izdavanje Tehničkog leksikona od 3. VII. 1976. tadašnji je glavni urednik Tehničke enciklopedije Hrvoje Požar napisao:

»Bila bi promašena svrha novog djela kad bi se i u Tehničkom leksikonu zadržala razina Tehničke enciklopedije, koja je koncipirana kao zbornik monografija, a djelomično i kao udžbenik za visoki stupanj naobrazbe...Tehnički leksikon trebao bi biti pisan stručno, ali popularno i pristupačno širokom krugu interesenata sa srednjoškolskom naobrazbom, dakle, osim tehničara i inženjera, liječnicima, pravnicima, ekonomistima i visokokvalificiranim radnicima, te svima onima koji se zanimaju za tehniku... Za pripremu prve verzije alfabetara mogao bi poslužiti indeks pojmova iz dosada izišlih svezaka Tehničke enciklopedije... te prijevod pojmova iz nekog stranog leksikona....Pri izradi prijevoda pojmova mora se osigurati upotreba adekvatnog hrvatskog nazivlja.«

Elaboratu je prethodio Prijedlog za raspravu od 29. VI. 1976. u kojem se kaže:

»Možda bi u TL trebalo obraditi i neke pojmove iz medicinske, poljoprivredne, šumarske, i pomorske enciklopedije, pogotovo jer su 3 posljednje osobito karakteristične za našu zemlju.«

Posljednji svezak Tehničke enciklopedije izašao je 1997. s kazalom manjega opsega no što se do tada predviđalo (oko 10000 pojmova), a zbog kompleksnosti projekta, o pokretanju drugoga izdanja nije se više razmišljalo. Leksikon kakav je H. Požar zamislio 1976. također nije realiziran, već je potkraj 2001. pokrenut projekt jednosveščanoga Tehničkoga leksikona ${ }^{36}$ (objavljenoga 2008) pod vodstvom fizičara, matematičara i leksikografa Zvonimira Jakobovića kao glavnoga urednika, koji je u sažetoj leksikografskoj formi donio 8033 članka posvećena tehničkim pojmovima, na ukup-

36 Tehnički leksikon. Zagreb 2007. 
no 1220 stranica, a opremljen je s 626 crteža, 257 fotografija te 110 tablica. Kako se ističe u radu D. Borasa i Z. Jakobovića ${ }^{37}$ :

\Tehnički leksikon projekt je Leksikografskoga zavoda koji obrađuje tehničke i srodne pojmove kojem je prva zadaća sustavno okupljanje hrvatskoga nazivlja u području tehnike te da bude ... priručnik i savjetnik za stvaranje i primjenu hrvatskoga tehničkog nazivlja.»

Stoga, iako Tehnički leksikon formalno ne donosi informacije o povijesti i trenutačnom stanju tehnike u Hrvatskoj, ima važnu ulogu u formiranju nacionalnoga pristupa tehnici, usustavljujući njezino tehničko nazivlje na hrvatskom jeziku. Osim toga, pruža i poveznicu domaće terminologije sa svjetskom, donoseći usporedno indeks pojmova (svojevrstan tehnički rječnik) na hrvatskom, engleskom, njemačkom i ruskom jeziku.

\section{Hrvatska tehnička enciklopedija}

Sazdan na zasadama dotadašnjih zavodskih izdanja te nastavljajući se na njih, unatrag pet godina pokrenut je projekt Hrvatske tehničke enciklopedije (HTE) ${ }^{38,39}$ radi kontinuiranoga prikupljanja i usustavljivanja znanja o povijesti i današnjim dosezima tehnike u Hrvatskoj. Povezujući znalce i znanstvenike koji se bave istraživanjem te umrežujući fragmentirane spoznaje i raznovrsne izvore u cjelovitu sintezu, cilj je projekta pridonijeti stvaranju spoznaje o bogatoj hrvatskoj nacionalnoj tehničkoj baštini, te održivosti znanosti, tehnike, inovacija i industrije u društvenom i kulturnom kontekstu.

Projekt Hrvatske tehničke enciklopedije pokrenuo je Leksikografski zavod Miroslav Krleža (LZMK) odlukom Ravnateljstva od 1. IV. 2014., kada je za glavnoga urednika imenovan inženjer arhitekture i leksikograf Zdenko Jecić. Interes Hrvatske akademije znanosti i umjetnosti (HAZU) i Akademije tehničkih znanosti Hrvatske (HATZ) za uključivanje u ovaj projekt rezultirao je Protokolom o suradnji, potpisanim 3. IX. 2014. između LZMK-a, HAZU-a i HATZ-a. Potpisivanju je prethodilo nekoliko sastanaka iste godine, koje su inicirali akademik Stjepan Jecić, tadašnji tajnik Razreda za tehničke znanosti HAZU-a, i prof. dr. sc. Vladimir Andročec, predsjednik HATZ-a, a koji predstavljaju prvi oblik suradnje tih institucija

37 D. Boras, Z. Jakobović: »Tehnički leksikon Leksikografskoga zavoda i hrvatsko tehničko nazivlje u izradbi i pripremi novih normi«, Savjetovanje Hrvatska normizacija i srodne djelatnosti: tehničko uskladivanje na putu prema Europskoj uniji (zbornik radova). Zagreb 2003., str. 123-128.

38 Hrvatska tehnička enciklopedija, sv. I. Zagreb 2018.

39 Hrvatska tehnička enciklopedija - Portal hrvatske tehničke baštine. Zagreb 2018. (http://tehnika.lzmk.hr/; pristupljeno 20. III. 2019) 
na zajedničkome projektu. Protokolom je pružena potpora projektu HTE, te je predviđen angažman institucija i njihovih članova u ostvarenju projekta.

Uredničko vijeće, kao temeljno savjetodavno tijelo projekta, sastavljeno od predstavnika mjerodavnih institucija (Stjepan Jecić, Sibila Jelaska, Božidar Liščić HAZU, Vladimir Andročec, Milena Mandić, Srećko Pegan, Nedeljko Perić, Dubravko Rogale, Zdravko Terze - HATZ, Zvonimir Jakobović, Slaven Ravlić LZMK, Damir Boras - Sveučilište u Zagrebu, Davor Fulanović - Tehnički muzej »Nikola Tesla«), prvi je sastanak održalo 24. XI. 2015.

Zavodska redakcija leksikografa urednika, koji u cjelini ili dijelu radnoga vremena rade na projektu, postupno se popunjavala, te se s početnih tri, do početka 2019. popela na sedam članova, a Zavod kao nositelj projekta pruža logističku potporu znatnoga broja djelatnika stručnih službi.

Rezultati rada na projektu su službeno predstavljeni javnosti 10. XII. 2018., na dan 100. obljetnice odluke o osnivanju Tehničke visoke škole u Zagrebu, kada je iz tiska izašao 1. svezak Hrvatske tehničke enciklopedije, te je dovršena unaprijeđena mrežna inačica Hrvatske tehničke enciklopedije - Portal hrvatske tehničke baštine.

Enciklopedija je oblikovana kao usporedno tiskano i mrežno (online) izdanje, po čemu predstavlja prvijenac na ovim prostorima. Tiskano je izdanje usmjereno korisnicima naklonjenima tradicionalnom mediju te omogućuje trajnu pohranu ostvarenja ovoga projekta u fizičkom obliku, u knjižnicama i kućnim bibliotekama. Mrežno izdanje Portal hrvatske tehničke baštine, obogaćeno dodatnim sadržajima i prednostima novih informacijskih tehnologija, jest portal znanja i polazišna točka za istraživanje.

\section{Tiskano izdanje Hrvatske tehničke enciklopedije}

Tiskano izdanje HTE obuhvaća četiri sveska, od kojih svaki obrađuje jednu zaokruženu tematsku cjelinu, na način sličan kao što se to predlagalo učiniti s Tehničkom enciklopedijom 1951. Pri podjeli na cjeline, u obzir se uzeo tradicionalni ustroj tehničkoga visokoga školstva u Hrvatskoj, točnije Tehničkoga fakulteta sveučilišta u Zagrebu, iz kojega su 1956/57. proistekla četiri fakulteta: Arhitektonsko-građevinsko-geodetski, Elektrotehnički, Strojarsko-brodograđevni i Tehnološki fakultet.

Uvjetovana time i pragmatičnim razlozima, raspodjela područja po svescima predviđena je na način prikazan u tablici 5. Posljednji će svezak obuhvatiti i opće tehničke pojmove zajedničke svim strukama, opći prikaz razvoja tehnike u pojedinim hrvatskim gradovima i vremenskim razdobliima. Neka područja, kao npr. vojna ili medicinska tehnika, bit će obrađena u sklopu drugih struka u više svezaka. Svesci će se dovršavati i tiskati jedan za drugim, u pravilnim vremenskim razmacima prilagođenima dinamici suvremenoga doba. 
Tablica 5. Raspodjela područja $H T E-a$ po svescima

\begin{tabular}{|l|l|l|l} 
Svezak 1 & Svezak 2 & Svezak 3 & Svezak 4 \\
\hline brodogradnja & biotehnologija & arhitektura & elektrotehnika \\
pomorstvo & drvna tehnika & gradevinarstvo & energetika \\
promet & grafička tehnologija & geodezija & informatika \\
strojarstvo & kemijska tehnologija & & mjeriteljstvo \\
zrakoplovstvo & metalurgija & nuklearna tehnika \\
& prehrambena tehnologija & & računarstvo \\
& poljoprivredna tehnika & & tehnika općenito \\
& rudarstvo & & temeljne tehničke znanosti $i$ \\
& tekstilna tehnologija & & \\
& zaštita okoliša & &
\end{tabular}

Pojedine teme obrađuju se u makropedijskim člancima posvećenima općim tehničkim pojmovima, koji donose sintezu niza zasebnih pojmova vezanih uz određeno područje. Uz to, donose se članci o pojedinim osobama, institucijama, poduzećima, udrugama, časopisima, za koje se smatra da predstavljaju važnu sastavnicu hrvatske tehničke baštine; kao poveznica pojedinih pojmova s artefaktima dostupnima javnosti oblikovani su i članci o muzejima u kojima se oni čuvaju.

Članci koji obrađuju opće tehničke pojmove zasnovani su na pretpostavci da je ta građa iz aspekta općih tehničkih znanja, zajedničkih za cijeli svijet, već iscrpno obrađena u Tehničkoj enciklopediji i drugim zavodskim izdanjima (na koja u mrežnom izdanju vode poveznice), u drugoj literaturi i na različitim mrežnim stranicama. Stoga je početni dio takvih članaka u kojem se objašnjava što je nešto, kako to funkcionira, koji su mu sastavni dijelovi ili kako se razvrstava, jednako kao i prikaz razvoja u svijetu, kratak i temeljan, dok se veći dio članka (najmanje 2/3) posvećuje obradbi teme u Hrvatskoj. To vrijedi za sve takve članke bez iznimke, pa pri njihovu odabiru ključnu ulogu ima pitanje ima li se o povijesti, razvoju i sadašnjem stanju u Hrvatskoj što pisati. Struktura oglednoga članka prikazana je na slici 1. 


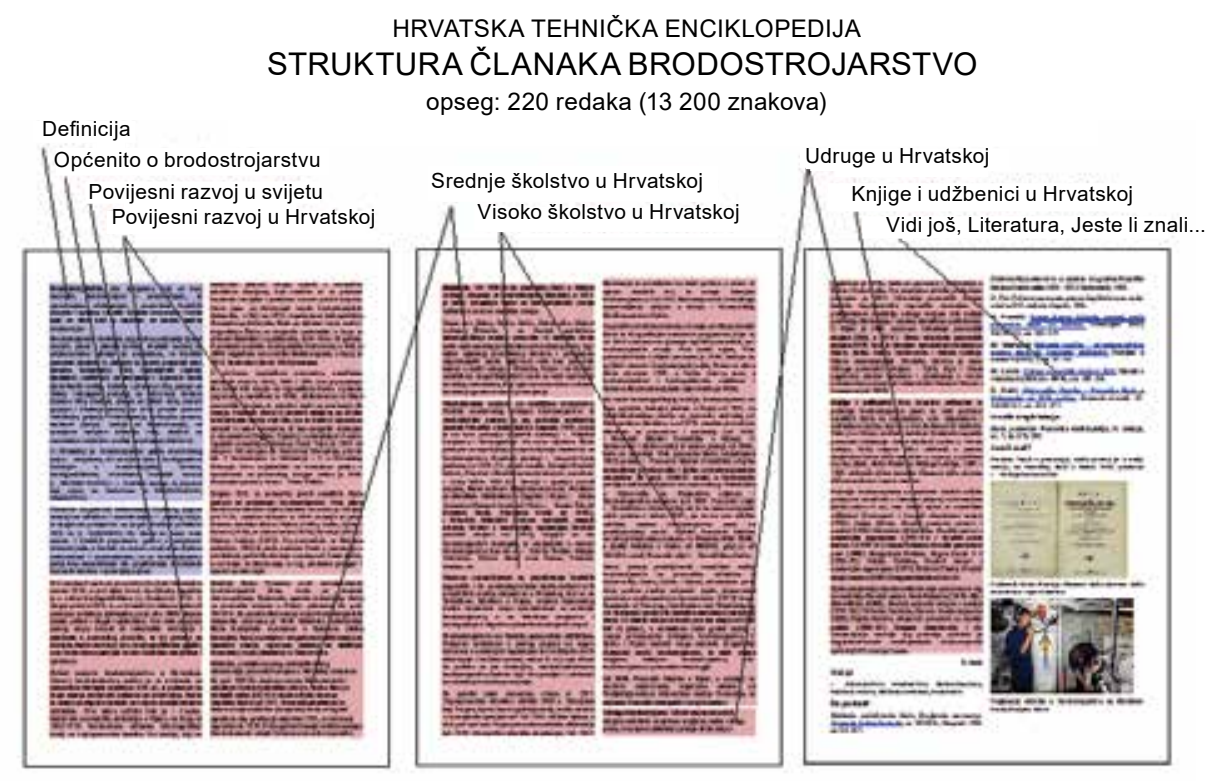

Slika 1. Struktura oglednoga članka HTE

Uz istaknute Hrvate i osobe hrvatskoga podrijetla obrađuju se i pripadnici drugih naroda rođeni na području današnje Hrvatske, bez obzira na to gdje su živjeli i djelovali, kao i stranci koji su živjeli i djelovali na ovome prostoru, osobe koje su zaokružile svoje životno djelo, ali i još uvijek djelatni suvremenici. Pri odabiru osoba Enciklopedija nastoji ne opteretiti se previše biografijama, pa su kriteriji za uvrštavanje razmjerno strogi, od rijetkih pojedinaca važnih za čovječanstvo u cjelini do osobito istaknutih, npr. fakultetskih profesora (akademici, professori emeritusi, redoviti članovi i emeritusi HATZ-a, dobitnici državnih nagrada za znanost, dekani velikih fakulteta, dugogodišnji urednici važnih časopisa). Ipak, i uz takve pretpostavke, HTE će ukupno obraditi oko 1500 osoba.

Slično kao i pri izboru osoba, izbor poduzeća nastoji se ograničiti kako bi ih u Enciklopediji u konačnici bilo obrađeno 500 najvažnijih, pri čemu su odlučujuće njihova dugovječnost (tradicija), veličina u razdoblju najvećega prosperiteta te važnost u razvoju tehnike. 


\section{Mrežno izdanje Hrvatske tehničke enciklopedije - Portal hrvatske tehničke baštine}

Osnovu mrežne pojavnosti projekta čini mrežno izdanje HTE, koja zajedno s drugim digitalnim sadržajima vezanima uz istu temu čini Portal hrvatske tehničke baštine. U želji da projekt bude dostupan današnjim korisnicima, naviknutima na dohvat bilo koje informacije jednim klikom, od njegovih se početaka razvijala mrežna inačica zasnovana na slobodnom pristupu te zasadama otvorene znanosti i javnoga znanja. Na mrežnim stranicama projekta slobodnoga pristupa objavljuje se članak po članak, kako bivaju dovršeni, pa se razvoj Portala može kontinuirano pratiti u javnosti, koja se poziva na suradnju putem priloga, komentara i primjedaba. Svi su članci potpisani te je naznačen datum njihova objavljivanja, odnosno ažuriranja.

Koristeći se blagodatima novih tehnologija, te uz obilatu uporabu metapodataka koji prate svaki članak, stvorena je semantička mreža koja omogućuje ekstenzivno unutarnje umrežavanje te povezivanje s vanjskim izvorima poput knjižnica, muzeja, digitalnih zbirki, arhiva videozapisa ili mrežnih stranica posvećenih temi koju članak obrađuje. Uz to, digitalizirano je svih 13 svezaka Tehničke enciklopedije, koje se posljednji svesci inače mogu naći samo u knjižnicama i antikvarijatima, a predstavljaju sadržajnu dopunu građe koja se obrađuje. U planu je također digitalizacija drugih zavodskih izdanja, poput Tehničkoga leksikona, članci kojega bi bili povezani s člancima HTE, pružajući odličnu terminološku i višejezičnu nadopunu. Tako koncipirane mrežne stranice projekta nadišle su razinu mrežnih enciklopedija. Postavši platformom za generiranje, diseminaciju i umrežavanje znanja te mjestom kolaboracije i kooperacije među priređivačima sadržaja i njihovih korisnika, trajnoga ažuriranja i dopunjavanja sadržaja, poput drugih suvremenih enciklopedičkih projekata u digitalnom okruženju, Portal hrvatske tehničke baštine predstavlja dio znanstvene i stručne infrastrukture.

Snalaženje na Portalu hrvatske tehničke baštine moguće je pretraživanjem sadržaja (engl. searching) ili pregledavanjem sadržaja (engl. browsing). Pretraživanje se obavlja uz pomoć tražilice (za pretraživanje naslova članaka ili cijeloga teksta) i napredne tražilice (za postavljanje složenih upita). Pregledavanje sadržaja (navigacija) omogućeno je prema područjima ili abecedno prema naslovima članaka.

Područja (struke) hijerarhijski su uređena taksonomijska klasifikacija pojedinih dijelova tehnike, nalik stablu znanja, a organizirana su u tri razine (šira područja, područja, uža područja). Kako bi se osiguralo da se svaki obrađeni pojam može razvrstati u neku semantički povezanu skupinu srodnih pojmova, pri sastavljanju taksonomije rukovodilo se hrvatskim Pravilnikom o znanstvenim područjima, poljima i granama, povijesnim i tradicionalnim podjelama tehničkih djelatnosti te praktičnim potrebama enciklopedije. Pregledavanje sadržaja po područjima omogućeno je na posebnoj stranici Portala. 
Kategorije članaka. Prema sadržaju i načinu obradbe, članci su podijeljeni u kategorije (opći tehnički pojmovi, osobe, ustanove, poduzeća, muzeji, udruženja, časopisi) i potkategorije (npr. za osobe su to izumitelji, znanstvenici, gospodarstvenici i dr.). Tako se omogućuje grupiranje članaka prema strukturi sadržaja i podatcima koji se donose, izdvajanje metapodataka, a time i napredno pretraživanje i postavljanje složenih upita.

Dopunski podatci. Na kraju članaka donosi se izbor drugih članaka iz Enciklopedije koje korisnik može pročitati kao dopunu tekstu (Vidi još), izbor iz preporučene literature s bibliografskim referencama (Što pročitati?), internetske poveznice na relevantne mrežne stranice (Mrežne poveznice), poveznice ili bibliografske reference na članke iz drugih zavodskih izdanja ( $I z$ arhive $L Z M K-a$ ), te prijedlozi za obilazak pojedinih artefakata, muzejskih zbirki ili spomenika kulturne baštine (Što posjetiti?). U planovima za daljnji razvoj Portala predviđa se oblikovanje Virtualnoga muzeja hrvatske tehničke baštine, koji će u jednom repozitoriju okupljati opise i poveznice svih artefakata iz rubrike Što posjetiti?, te Virtualne knjižnice hrvatske tehničke baštine, koja će okupljati i omogućivati pretraživanje svih bibliografskih jedinica iz rubrike Što pročitati?.

Infookviri. Uz svaki su članak predviđeni tablični prikazi najvažnijih informacija (infookviri). Njihova je struktura specifična za svaku od kategorija članaka, a sadržavaju naslov članka, nosivu ilustraciju, definiciju (kvalifikativ), označene (tagirane) opće podatke o subjektu, kategoriju članka, šire područje, područje i uže područje članka. Podatci iz infookvira ujedno su metapodatci, koji omogućuju unutarnje i vanjsko povezivanje, postizanje interoperabilnosti s drugim projektima, te postavljanje složenih upita u naprednoj tražilici. U prikazu na pametnim telefonima s ograničenom veličinom zaslona, infookviri dolaze na početku članka te pružaju osnovne podatke koje korisnik u letimičnom pregledu može brzo dohvatiti.

Uz najširu uporabu suvremenih informacijskih tehnologija za povezivanje i pronalaženje podataka iz područja digitalne humanistike, time se ostvaruje jedan od ciljeva projekta kao platforme za razvoj enciklopedijske koncepcije u duhu nadolazećega doba.

\section{Zaključak}

Radom je prikazano kako su povijest i sadašnje stanje tehnike u Hrvatskoj nedovoljno istraženi te nedostaju pregledna sintetska djela literature, što je utjecalo i na enciklopedička djela. Načela strukovnih djela suvremene hrvatske enciklopedistike koja je uspostavila Pomorska enciklopedija, zahvaljujući pripremljenoj građi za izradbu Hrvatske enciklopedije (1941-45) te dobroj istraženosti nacionalne sastavnice toga područja, Tehnička enciklopedija nije uspjela slijediti. Iako kapitalno djelo i jedina literatura u školovanju mnogih studenata tehničkih fakulteta, nedostaje joj obraćanje širemu krugu korisnika, te članci ili njihovi dijelovi koji bi obradili nacionalnu sa- 
stavnicu općih tehničkih pojmova iz povijesnoga i kulturno-društvenoga aspekta, važne osobe, poduzeća, ustanove, udruge, časopise i sl. Uviđajući nedostatke takva pristupa, sastavljači Tehničke enciklopedije predvidjeli su obradbu tih tema u drugim temeljnim izdanjima LZ-a, napose Enciklopediji Fugoslavije, što se međutim nije ostvarilo ni u jednom od njezinih dvaju izdanja. Tehnika se počela sustavno obrađivati tek pojavom novijih nacionalnih hrvatskih djela, Hrvatskoga biografskoga leksikona, Hrvatskoga leksikona i Hrvatske enciklopedije, iako je i dalje ostala prisutna potreba za temeljitijom i sustavnijom obradbom hrvatske tehnike. Korak dalje prema usustavljenju hrvatske tehničke baštine, stvaranju podloge za daljnja istraživanja, razvoj i utemeljenje povijesti tehnike u Hrvatskoj te promjenu društvene percepcije toga područja predstavlja Hrvatska tehnička enciklopedija, koja se nastavlja na Tehničku enciklopediju, obrađujući one segmente koji su TE- $u$ najviše nedostajali. U želji da se ostvari djelo prilagođeno suvremenom dobu, uz tiskano izdanje HTE- $a$ u četiri sveska, usporedno dolazi i mrežno izdanje Portal hrvatske tehničke baštine koji, okupljajući digitalizirane sadržaje i uvodeći nove funkcionalnosti, predstavlja platformu za povezivanje i umrežavanje sadržaja toga područja.

\section{LITERATURA}

Pomorska enciklopedija, upute urednicima i suradnicima. Zagreb 1949.

Znanost u Hrvata: Prirodoslovlje i njegova primjena (katalog izložbe). Zagreb 1996.

Boras, Damir, Jakobović, Zvonimir: »Tehnički leksikon Leksikografskoga zavoda i hrvatsko tehničko nazivlje u izradbi i pripremi novih normi«, Savjetovanje Hrvatska normizacija i srodne djelatnosti: tehničko uskladivanje na putu prema Europskoj uniji (zbornik radova). Zagreb 2003., str. 123-128.

Jakobović, Zvonimir: »Pothvat Tehničke enciklopedije«, Radovi Leksikografskog zavoda Miroslav Krleža, 10(2001), str. 121-130.

Klemenčić, Mladen: »Dvije nacionalne enciklopedije«, Studia lexicographica, 2(2008) 2, str. 27-37.

Marušić, Rikard: »Prilozi za historijat tehničke enciklopedije. Činjenice i sjećanja«, Radovi Leksikografskog zavoda Miroslav Krleža, 6(1997), str. 75-90.

Muljević, Vladimir: »Tehnika i tehničke znanosti«, Hrvatska $i$ Europa: kultura, znanost $i$ umjetnost, sv. III. Barok i prosvjetiteljstvo (XVII.-XVIII. stoljeće). Zagreb 2003., str. 417-429.

Muljević, Vladimir: »Razvitak i stanje tehnike u Hrvatskoj u XIX. stoljeću«, Hrvatska i Europa: kultura, znanost $i$ umjetnost, sv. IV. Moderna hrvatska kultura od preporoda do moderne (XIX. stoljeće). Zagreb 2003., str. 779-785.

Muljević, Vladimir: »U povodu objavljivanja 13. završnog sveska Tehničke enciklopedije«, Hrvatski glasnik intelektualnog vlasnistva, 4(1997) 5, str. 1791-1794.

Starčević Stančić, Irina, Kraus, Cvijeta: »Hrvatska enciklopedija - od tiskanoga do mrežnog izdanja«. Studia lexicographica, 8(2014) 1, str. 99-116.

Švab, Mladen: »Mate Ujević, utemeljitelj suvremene hrvatske enciklopedike«, Radovi Leksikografskoga zavoda »Miroslav Krleža«, 2(1992), str. 9-36.

Ujević, Mate: Primjerci članaka Pomorskog leksikona, Zagreb 1944. 


\section{ENCIKLOPEDIČKA DJELA}

Enciklopedija fugoslavije, I. izdanje, sv. 1-8. Zagreb 1955-71.

Enciklopedija leksikografskog zavoda, I. izdanje, sv. 1-7. Zagreb 1955-64.

Enciklopedija leksikografskog zavoda, II. izdanje, sv. 1-6. Zagreb 1966-69.

Enciklopedija likovnih umjetnosti, sv. 1-4. Zagreb 1959-66.

Hrvatska enciklopedija, sv. 1-5. Zagreb 1941-45.

Hrvatska enciklopedija, sv. 1-11. Zagreb 1999-2009.

Hrvatska tehnickka enciklopedija, sv. I. Zagreb, 2018.

Hrvatska tehnička enciklopedija - Portal hrvatske tehničke baštine, Zagreb 2018. (http://tehnika.lzmk.hr/; pristupljeno 20. III. 2019)

Hrvatski biografski leksikon, sv. 1-8. Zagreb 1983-2013.

Hrvatski biografski leksikon. Zagreb 2009. (http://hbl.lzmk.hr/; pristupljeno 19. III. 2019)

Hrvatski leksikon, sv. 1-2. Zagreb 1996-97.

Medicinska enciklopedija, I. izdanje, sv. 1-10. Zagreb 1957-65.

Muzička enciklopedija, I. izdanje, sv. 1-2. Zagreb 1958-63.

Opća enciklopedija, sv. 1-9. Zagreb 1977-88.

Pomorska enciklopedija, I. izdanje, sv. 1-8. Zagreb 1954-64.

Šumarska enciklopedija, I. izdanje, sv. 1-2. Zagreb 1959-63.

Tehničk enciklopedija, sv. 1-13. Zagreb 1963-97.

Tehnički leksikon. Zagreb 2007. 


\title{
FROM THE TEHNIČKA ENCIKLOPEDIЭA TO THE HRVATSKA TEHNIČKA ENCIKLOPEDIFA
}

\author{
Zdenko Jecić \\ The Miroslav Krleža Institute of Lexicography, Zagreb \\ zdenko.jecic@lzmk.hr
}

\begin{abstract}
The technological heritage of Croatia, the history and current state of technology in Croatia are relatively poorly researched and documented in literature, and overviews regarding this field are noticeably absent. This state of affairs is partially reflected in contemporary Croatian encyclopaedics. In contrast to the Pomorska enciklopedija (Maritime Encyclopaedia) or Sumarska enciklopedija (Encyclopaedia of Forestry) of the Miroslav Krleža Institute of Lexicography, the Tehnička enciklopedija (TE - Encyclopaedia of Technology), a major work encompassing 13 volumes and long-time indispensable reference book for students of faculties of engineering, focused on macropeadic interpretation of general technological terms without a systematic examination of the history and current state of affairs in Croatia. The Hrvatska tehnicka enciklopedija (HTE - Croatian encyclopaedia of Technology) continues the $T E$ and serves to complement it, including national topics and containing articles covering general terms, biographies, companies and institutions, journals and associations, striving to adapt the texts to a broader circle of users. The HTE project builds upon the values of the traditional encyclopaedic concept of organising and disseminating consolidated knowledge, adapted to the digital age, and is simultaneously published in printed and electronic form. It is expected that this approach will contribute towards increasing familiarity with Croatian technology and thus improve its perception in a cultural and social context.
\end{abstract}

Keywords: Tehnička enciklopedija (Encyclopaedia of Technology); Hrvatska tehnička enciklopedija (Croatian Encyclopaedia of Technology); Portal hrvatske tehničke baštine (Croatian Technological Heritage Portal) 